\title{
Morphology-based classification of functional groups for potamoplankton
}

\author{
Ning CHEN, ${ }^{1}$ Ling LIU,${ }^{*}$ Yanfeng LI, ${ }^{1}$ Danying QIAO,${ }^{1}$ Yuanpo LI, ${ }^{2}$ Ying ZHANG,${ }^{1,3}$ Yiyan $\mathrm{LV}^{1}$ \\ ${ }^{1}$ College of Hydrology and Water Resources, Hohai University, No. 1 Xikang Road, Gulou District, Nanjing City, 210098, Jiangsu \\ Province; ${ }^{2}$ Nanjing Institute of Geography \& Limnology, Chinese Academy of Sciences, No. 73 Beijing East Road, Xuanwu District, \\ Nanjing City, 210098, Jiangsu Province; ${ }^{3}$ Water Resources Department of Jiangsu Province, No. 5 Shanghai Road, Gulou District, \\ Nanjing City, 210029, Jiangsu Province, China \\ *Corresponding author: lingliu504@163.com
}

\begin{abstract}
Simple morphological traits of phytoplankton have proven to correlate well with the functional properties of taxa. A logical way of distinguishing functional groups of phytoplankton is to cluster species according to their morphological traits, instead of phytosociological traits, which are difficult to measure and incomplete for the vast majority of phytoplankton species. This novel approach inspired the establishment of morphologically based functional groups (MBFG) for lake phytoplankton. This study considers the MBFG as a potentially suitable tool for investigating and comparing the potamoplankton assemblages in riverine ecosystems. This study constructed a special version of $M B F G$ that is aimed at rivers, termed $M B F G_{R} . M B F G_{R}$ is based on information obtained from more than 800 samples of potamoplankton and zooplankton collected from 101 rivers located in four climate zones. Their habitat templates were also described by the thresholds of the environmental variables that promote group dominance. Despite its similar framework with $M B F G, M B F G_{R}$ emphasized the presence of flagella, size and shape, exoskeletal structures, life strategy and subdivision of diatoms. Their habitat templates are outlined by additional factors connected to hydrology and river types. Moreover, each discussed template includes consideration of grazing by zooplankton. Theoretically, $M B F G_{R}$ is better than $M B F G$ because it can sensitively capture the ecological preferences of phytoplankton groups most associated with rivers and provides empirical values to reflect the environmental conditions in riverine ecosystems.
\end{abstract}

Key words: Functional groups; habitat template; algae; phytoplankton; river; zooplankton predation.

Received: January 2015. Accepted: April 2015.

\section{INTRODUCTION}

The focus of current research on phytoplankton ecology is on finding an effective substitute for the traditional taxonomic approach to understand phytoplankton patterns in different types of aquatic systems (Salmaso et al., 2012). The phytosociological approach is aimed at linking phytoplankton community and environmental factors (Reynolds, 1980; Reynolds, 1984), and has been highly valued for decades. It stimulated the proposition of functional groups (FG) (Reynolds et al., 2002). Subsequently, morpho-functional groups (MFG) combining morphological traits led to a relative simplification of the functional scheme (Salmaso and Padisák, 2007). According to the growing reports by phytoplankton ecologists worldwide, FG and MFG usually provide reliable predictions of environmental conditions in various aquatic ecosystems (Devercelli and O'farrell, 2013), thereby proving the validity of such approaches as effective tools for the assessment of phytoplankton community structure (summarized by Padisák et al., 2009). However, the relationship of morphological traits and phytosociological traits were not evaluated thoroughly until Kruk et al. (2010) proposed the morphologically based functional groups (MBFG). The current paucity of information on species-specific physiological traits limits our ability to arrive at a priori functional classification. Given the expense and practical limitations of systematically investigating physiological traits, arriving at a functional classification of phytoplankton based on simple morphology which could be used for ecological prediction, becomes possible (Kruk et al., 2010). After measuring ten physiological traits, seven (maximum growth, sink velocity, Si half-saturation constant for growth in laboratory, abundance, maximum biomass, mean biomass, and biomass standard deviation in fields) were shown to be closely associated with morphological traits (volume, maximum linear dimension, surface area, and the presence of mucilage, flagella, gas vesicles or aerotopes, heterocysts and siliceous exoskeletal structures). Consequently, MBFG clustered more than 700 species into seven morphologically distinctive groups. These species were from more than 200 lakes situated in climate zones that ranged from subpolar to tropical ones. Differences in simple morphological traits among MBFGs well reflected the significant differences in functional characteristics and habitat templates independently from the geographical location (Kruk et al., 2010; Kruk and Segura, 2012).

Studies applying MBFG (Pacheco et al., 2010; Segura et al., 2013) and those compared MBFG with FG and 
MFG (Gallego et al., 2012; Izaguirre et al., 2012; Hu et al., 2013) in a range of lentic water (lakes, ponds, and reservoirs) commended the high simplification and practicality of MBFG. Given that the MBFG was initially proposed for lakes, only a few researches have used it to investigate and compare the phytoplankton assemblages in riverine ecosystems and have concluded low sensitivity (Centis et al., 2010; Stanković et al., 2012; Mihaljević et al., 2015). This consequence can be inferred from the following: i) the predominant presence of only one diatom group; and ii) the poor general-representativeness of some species that are only important for lakes. Such flaws are rooted in the targeted data source (lakes) of MBFG formation rather than the thought process behind the classification. Thus far, existing classification approaches based on ecological functions are all aimed at lakes where phytoplankton communities are relatively abundant and diverse. Rivers are as important as lakes for water management (Wehr and Descy, 1998). MBFG is a potentially suitable tool for riverine study, but its misuse can have serious consequences for interpreting ecological processes (Salmaso et al., 2014). Thus a special version of MBFG for potamoplankton is required and the development of such a version would be meaningful.

Rivers differ from lakes in many aspects, including the water residence time, drainage area, water depth, stream flow, and water clarity, thereby resulting in different ecological structures and functions (Søballe and Kimmel, 1987). Potamoplankton are the primary producers of riverine ecosystems; they directly reflect such differences through biomass proportion, community composition, and morphological traits (Reynolds and Descy, 1996; De Emiliani, 1997). There is an annual cycle of potamoplankton succession (Muylaert et al., 2000) and an analogy of annual cycle in stratified lakes with feedback mechanisms (Gamier et al., 1995). Both studies emphasized the large proportion and long survival of diatoms in rivers compared with lakes. Moreover, other algae such as flagellates (Cloern et al., 1983; De Oliveira and Calheiros, 2000; Gómez et al., 2004), filamentous cyanobacteria (Köhler and Hoeg, 2000), non-diatoms that indicate altered conditions (Mihaljević et al., 2013), are also important. The composition and persistence of potamoplankton assemblages in riverine ecosystems mainly depend on physical (light, water temperature, and turbidity) and hydrological factors (discharge, flow velocity, water level, suspended sediment concentration and water residence time) (Köhler, 1993; Gosselain et al., 1994; Kirk, 1994; Reynolds et al., 1994; Reynolds and Descy, 1996; Train and Rodrigues, 1997; Centis et al., 2010; Salmaso and Zignin, 2010), and resolved silicate concentration (Dortch and Whitledge, 1992; Tavernini et al., 2011). All of these can be distinguished from those in lakes. Therefore, if morphological classification is especially suited for potamoplankton, this approach probably attaches more importance to the subdivision of diatoms, life forms, traits of flagella, and siliceous structures. Furthermore, habitat templates are supposed to be outlined by additional suitable conditions that indicate river types. Several recent studies showed that the differences among river types (e.g., upper and down streams) are defined in terms of their hydrology and their phytoplankton composition (Várbíró et al., 2007) because of floods (Stanković et al., 2012), climate, topography, and human activity (Abonyi et al., 2014).

In light of the previous studies on the MBFG of lakes, we attempted to construct a similar classification system, namely, $\mathrm{MBFG}_{\mathrm{R}}$, whose original data were all river cases, to meet a pressing need to study rivers through the phenotypic variability of potamoplankton. We hypothesized that particular environments will select phytoplankton based on the functional properties that are reflected by the differences in morphological traits among $\mathrm{MBFG}_{\mathrm{R}}$. The analysis and habitat template of each $\mathrm{MBFG}_{\mathrm{R}}$ environmental preference was established and compared with the MBFG of lakes. Moreover, zooplankton was taken into consideration because grazing exerts critical control over plankton dynamics (Reynolds, 1984; Gosselain et al., 1994; Gamier et al., 1995; Reynolds and Descy, 1996; De Emiliani, 1997).

\section{METHODS}

\section{Sampling and measurements}

A database of 531 species from 101 rivers located within four climate zones was compiled. This database covered a wide range of environmental characteristics [s, for the two Russian rivers in subpolar zone, information was obtained from unpublished sources (an ecological survey of large rivers of Russia by J. Skakalski, personal communication)]. The remaining 99 rivers were distributed in three climate zones of China and sampled for physical, chemical, and biological parameters during 2008-2013. Of the total number of rivers, 67 were sampled only once (12 rivers in spring, 19 in summer, 23 in autumn and 13 in winter), whereas 36 were sampled at least once every season ( 21 rivers seasonally and 15 bimonthly). The stream order of these rivers ranged from first to sixth. Among these rivers, 68 are located in plains and 33 in mountainous areas. The total drainage area of the 36 large rivers exceeded $50,000 \mathrm{~km}^{2}$. The investigation was conducted at middle-upstream of 34 rivers and at middle-downstream of 67 rivers (Tab. 1). A complete profile of the rivers studied is reported in Supplementary Tab. 1

The following variables were measured in situ: surface water temperature $\left(\mathrm{WT},{ }^{\circ} \mathrm{C}\right), \mathrm{pH}$, Chlorophyll- $a(\mathrm{Chl}-a, \mu \mathrm{g}$ $\mathrm{L}^{-1}$ ), and dissolved oxygen (DO, $\mathrm{mg} \mathrm{L}^{-1}$ ) with a portable YSI model 55 probe (YSI, Yellow Springs, OH, USA). The flow velocity $\left(v, \mathrm{~m} \mathrm{~s}^{-1}\right)$ was determined with a direct reading current meter FP211 (KANGGAOTE, Beijing, China). The light attenuation coefficient $\left(\mathrm{K}_{\mathrm{d}}, \mathrm{m}^{-1}\right)$ was calculated 
from in situ measurements of irradiance by a spectrum-submersible radiometer (SR9910-PC, Macam, England) (Kirk, 1994). The discharge $\left(Q, \mathrm{~m}^{3} \mathrm{~s}^{-1}\right)$ was represented by the mean value for the month from the nearest hydrological station. In the laboratory, the flow injection analyser (Skalar $\mathrm{SAN}++$, Breda, Netherlands) was used to measure total nitrogen (TN, mg L ${ }^{-1}$ ) and total phosphorus (TP, $\mathrm{mg} \mathrm{L}^{-1}$ ) concentrations. The soluble reactive silicate $\left(\mathrm{RSi}, \mathrm{mg} \mathrm{L}^{-1}\right)$ was measured by plasma emission chromatography ICAP (ICP6300, Thermo Scientific, Waltham MA, USA). The suspended sediment concentration ( $\mathrm{SSC}, \mathrm{g} \mathrm{L}^{-1}$ ) of upper $100 \mathrm{~cm}$ water was measured by an electronic balance (ME104E, Mettler Toledo, Zurich, Switzerland) after vacuum filtration $(0.45 \mu \mathrm{m})$ and drying.

Quantitative phytoplankton samples were fixed in situ with Lugol's solution. Counting was performed with an inverted microscope (OLYMPUS IX-70, Japan) following the Utermöhl method (Lund et al., 1958) at 400× magnification. The counting error was estimated according to Duarte et al. (1990). For each sample, at least 400 units (filament, colony, coenobium and single-celled organisms) were enumerated. We estimated the cell numbers per colony or filament, as well as the organism dimensions and maximum linear dimension (MLD, $\mu \mathrm{m})$. The individual volume $\left(\mathrm{V}, \mu \mathrm{m}^{3}\right)$ and surface area $\left(\mathrm{S}, \mu \mathrm{m}^{2}\right)$ were calculated according to the geometric equations of Hillebrand et al. (1999). The phytoplankton biomass ( $\left.\mathrm{mg} \mathrm{L}^{-1}\right)$ was converted from biovolume by using a method described by Hasle (1978) and Javornicky and Komárková (1973). For colonial organisms with mucilage, V and S calculations were made for entire colonies, including mucilage. The presence of aerotopes (Aer), flagella (Fla), mucilage (Muc), unicellularity (Uni), heterocysts (Het), exoskeletal structures (Exs) or siliceous structures (Si) was noted for each relevant organism.

To determine the zooplankton abundance (TZ, org $\mathrm{L}^{-}$ $\left.{ }^{1}\right)$, zooplankton were collected using a 30-cm-diameter plankton net (64- $\mu \mathrm{m}$ mesh) that was horizontally held below the surface in the upper part of the water column. A flow meter was placed next to the mouth of the net so that the total volume of river water filtered for each sample could be determined for use in density measurements. Samples were fixed with buffered formaldehyde (10\% final concentration). Before microscopic analysis, the fixed samples were concentrated and re-suspended in filtered river water up to $30 \mathrm{~mL}$ in volume. Individuals were enumerated and identified to genus level with an upright microscope (Olympus BX-51, Tokyo, Japan). The core body lengths $(\mu \mathrm{m})$ of individuals were noted.

\section{Data analysis}

A two-step cluster analysis was used to construct the $\mathrm{MBFG}_{\mathrm{R}}$ by classifying the species based on the eleven measured morphological traits (V, S, S/V, MLD, Aer, Fla, Muc, Het, Uni, Exs and Si). The Akaike Information Criterion (AIC) can reflect the model parsimony by combining the goodness-of-fit and the number of estimated model parameters (Akaike, 1973). The AIC helped us determine the optimum number of clusters, and each of the cluster solutions was compared. After clustering, outlier selection was performed with noise handling of $25 \%$ and no instance was picked out. All analyses were carried out using SPSS for Windows (ver. 20.0). Redundancy analyses (RDA) were used to estimate how much variance of the $\mathrm{MBFG}_{\mathrm{R}}$ biomass was explained by the environmental variables. Previously, a detrended correspondence analyses (DCA) was performed. The data showed a linear response, thus RDA was applied. Calculations were performed with the program CANOCO 5.0. The statistical significance of the first axis and of all the axes was tested by a Monte Carlo permutation test. The importance of each variable was assessed by forward selection.

To establish the habitat templates of each $\mathrm{MBFG}_{\mathrm{R}}$, a classification and regression tree (CART) was used. Unlike standard regression, this tree is constructed by the recursive

Tab. 1. Average and range (in brackets) of environmental variables of rivers included in this study for the different regions of the northern hemisphere, as follows: Subpolar, Temperate, Subtropical, and Tropical.

\begin{tabular}{|c|c|c|c|c|c|c|c|c|c|c|c|}
\hline Latitude & $\begin{array}{l}\text { No. of } \\
\text { rivers }\end{array}$ & $\begin{array}{l}\text { WT } \\
\left({ }^{\circ} \mathrm{C}\right)\end{array}$ & $\begin{array}{l}\text { Ice } \\
\text { cover }\end{array}$ & $\begin{array}{c}Q \\
\left(\mathrm{~m}^{3} \mathrm{~s}^{-1}\right)\end{array}$ & $\begin{array}{c}v \\
\left(\mathrm{~m} \mathrm{~s}^{-1}\right)\end{array}$ & $\begin{array}{l}\text { SSC } \\
\left(\mathrm{g} \mathrm{L}^{-1}\right)\end{array}$ & $\begin{array}{c}\mathbf{K}_{\mathrm{d}} \\
\left(\mathrm{m}^{-1}\right)\end{array}$ & $\begin{array}{c}\mathrm{TN} \\
\left(\mathrm{mg} \mathrm{L}^{-1}\right)\end{array}$ & $\begin{array}{c}\mathrm{TP} \\
\left(\mathrm{mg} \mathrm{L}^{-1}\right)\end{array}$ & $\begin{array}{c}\mathrm{Chl}-a \\
\left(\mu \mathrm{g} \mathrm{L}^{-1}\right)\end{array}$ & $\begin{array}{c}\text { RSi } \\
\left(\mathrm{mg} \mathrm{L}^{-1}\right)\end{array}$ \\
\hline Subpolar & 2 & $\begin{array}{l}10.2 \\
(3.7-19\end{array}$ & $\begin{array}{l}\text { Yes } \\
9.5)\end{array}$ & $\begin{array}{c}8835 \\
(300-27000)\end{array}$ & $\begin{array}{c}0.7 \\
(0.2-1.6)\end{array}$ & $\begin{array}{c}0.06 \\
(<0.001-0.86)\end{array}$ & $\begin{array}{c}1.3 \\
(36.1-0.4)\end{array}$ & $\begin{array}{c}2.16 \\
(0.063-20.99)\end{array}$ & $\begin{array}{c}0.344 \\
(0.015-5.060)\end{array}$ & $\begin{array}{c}7.5 \\
(<0.3-178)\end{array}$ & $\begin{array}{c}0.83 \\
(0.10-4.91)\end{array}$ \\
\hline Temperate & 25 & $\begin{array}{l}16.8 \\
(0.5-33\end{array}$ & $\begin{array}{l}\text { Yes } \\
3.7)\end{array}$ & $\begin{array}{c}812 \\
(3.7-10600)\end{array}$ & $\begin{array}{c}0.4 \\
(<0.05-4.0)\end{array}$ & $\begin{array}{c}0.78 \\
(<0.001-4.45)\end{array}$ & $\begin{array}{c}4.5 \\
(37.2-1.4)\end{array}$ & $\begin{array}{c}2.52 \\
(0.078-23.89)\end{array}$ & $\begin{array}{c}0.186 \\
(0.038-3.025)\end{array}$ & $\begin{array}{c}10.4 \\
(0.3-297)\end{array}$ & $\begin{array}{c}1.52 \\
(0.02-6.89)\end{array}$ \\
\hline Subtropical & 56 & $\begin{array}{l}20.6 \\
(8.0-31\end{array}$ & $\begin{array}{l}\text { No } \\
1.2)\end{array}$ & $\begin{array}{c}1256 \\
(2.8-36060)\end{array}$ & $\begin{array}{c}1.3 \\
(<0.05-5.7)\end{array}$ & $\begin{array}{c}0.11 \\
(<0.001-1.93)\end{array}$ & $\begin{array}{c}2.4 \\
(19.1-0.6)\end{array}$ & $\begin{array}{c}3.26 \\
(0.054-36.72)\end{array}$ & $\begin{array}{c}0.443 \\
(0.029-9.411)\end{array}$ & $\begin{array}{c}20.1 \\
(<0.3-395)\end{array}$ & $\begin{array}{c}3.63 \\
(0.01-8.90)\end{array}$ \\
\hline Tropical & 18 & $\begin{array}{l}25.0 \\
\quad(12.3-3\end{array}$ & $\begin{array}{r}\text { No } \\
38.5)\end{array}$ & $\begin{array}{c}1652 \\
(12-15070)\end{array}$ & $\begin{array}{c}1.0 \\
(<0.05-4.3)\end{array}$ & $\begin{array}{c}0.09 \\
(<0.001-1.65)\end{array}$ & $\begin{array}{c}1.6 \\
(9.4-0.5)\end{array}$ & $\begin{array}{c}0.57 \\
(0.028-22.05)\end{array}$ & $\begin{array}{c}0.096 \\
(0.011-0.493)\end{array}$ & $\begin{array}{c}4.9 \\
(<0.3-142)\end{array}$ & $\begin{array}{c}1.49 \\
(0.01-9.01)\end{array}$ \\
\hline
\end{tabular}

$W T$, water temperature; $Q$, discharge; $\mathrm{v}$, flow velocity; SSC, suspended sediment concentration; $K_{d}$ light attenuation coefficient; TN, total nitrogen; TP, total phosphorus; Chl-a, Chlorophyll-a; RSi, soluble reactive silicate. The detailed information is shown in the Supplementary Tab. 1. 
binary partitioning of the response variable into regions that are increasingly homogeneous (i.e. nodes) until no improvement is possible (Kruk and Segura, 2012). The final nodes are called leaves. At each node, the predictor variable that results in the most homogeneous partition of the response variable (measured by the sum of squared errors, SSE) is selected based on an optimization process (Breiman, 2001). This process continues until reduction of SSE is no longer achieved. The methods are easily interpretable and provide simple yes $(>)$ or no $(<)$ decision trees (Kruk and Segura, 2012). After constructing the full tree, this tree was pruned back by minimizing the cross-validated error to avoid overfitting (De'ath and Fabricius, 2000).

The Gasol model (Gasol, 1994) that was developed for nanoflagellates, allows assessment of the importance of top-down $v s$. bottom-up mechanisms. It helped in identifying the controlling direction when each $\mathrm{MBFG}_{\mathrm{R}}$ dominates a river. This model consists of a bivariate space where the (log)-transformed phytoplankton and zooplankton abundances are plotted. A maximum attainable abundance line (MAA) is computed. MAA depicts the zooplankton abundance that can be attained for a given phytoplankton abundance by assuming that zooplankton feeds only on phytoplankton, which is rarely achieved in natural systems. A mean realized abundance line (MRA) is deduced and summarized from observations. MRA represents the average level in nature. The location of data points below the MRA line indicates that the said ecosystem is mainly driven by top-down control, whereas bottom-up regulation is suggested when samples are located above the MAA line.

To evaluate the relative importance of dominant $\mathrm{MBFG}_{\mathrm{R}}$ biomass in driving the zooplankton predation, the river-samples were preselected and aggregated according to $\mathrm{MBFG}_{\mathrm{R}}$ dominance ( $>75 \%$ cases). Preliminary screening identified that the component river-cases had nearly identical results. To examine the relationships of dominant-group biomass and zooplankton abundance, leastsquares linear regression was used. Given the risk of spurious correlation (Jansson et al., 2010), relative comparisons of phytoplankton and zooplankton were prudent to make rather than focusing on the individual $\mathrm{r}^{2}$ values. Statistical analyses were performed with SPSS 20.0.

\section{RESULTS}

\section{Morphologically based functional groups from rivers}

Based on the morphological traits, the two-step cluster analysis separated potamoplankton species into eleven groups, named as $\mathrm{MBFG}_{\mathrm{R}}$. As expected, a similar framework and significant differences were observed between $\mathrm{MBFG}_{\mathrm{R}}$ and MBFG. Therefore the eleven groups were labelled according to their closest MBFG and marked with a suffix when necessary by considering the comparative study and use. All groups of $\mathrm{MBFG}_{\mathrm{R}}$ and their representative taxa are described in Tabs. 2 and 3, and the basis for classifying species is summarized in the dichotomous key in Tab. 4.

MBFG I was divided into two parts, namely, Groups RIa and RIb based on the absence or presence of flagella. Group RII was re-established for all flagellated organisms with exoskeletal structures and Group RII was subdivided into RIIa and RIIb based on size. Group RIII included all large filaments, whereas the MBFG III was restricted to filaments with aerotopes. Group RV excluded species with hard scales from MBFG V. MBFG VI was subdivided into Groups RVIa, RVIb and RVIc; these groups emphasized size and life form of diatoms. Group RIV and RVII seemed equivalent to MBFG IV and VII, respectively.

\section{Environmental effects on $\mathrm{MBFG}_{\mathrm{R}}$ and their dominance}

The results of redundancy analysis (RDA) indicated that the biomass of potamoplankton corresponding to the $\mathrm{MBFG}_{\mathrm{R}}$ was closely affected by environmental variables. The first two axes accounted for $77.1 \%$ of the variance (axis 1, 46.5\%; axis 2, 30.6\%). The Monte Carlo test indicated that the environmental variables were significantly correlated with the first axis $(\mathrm{P}=0.018)$, and the test of significance of all canonical axes was also significant $(\mathrm{P}=0.006)$. The first axis was mainly correlated with $\mathrm{K}_{\mathrm{d}}$, $v$, and RSi (intra-set correlation coefficients: 0.64, 0.64, and 0.49 , respectively), whereas the second axis was mainly defined by WT, SCC, TP, and TN (intra-set correlation coefficient: $-0.73,-0.26,-0.48$, and -0.42 , respectively). Fig. 1 showed the biplots (first two axes) of the

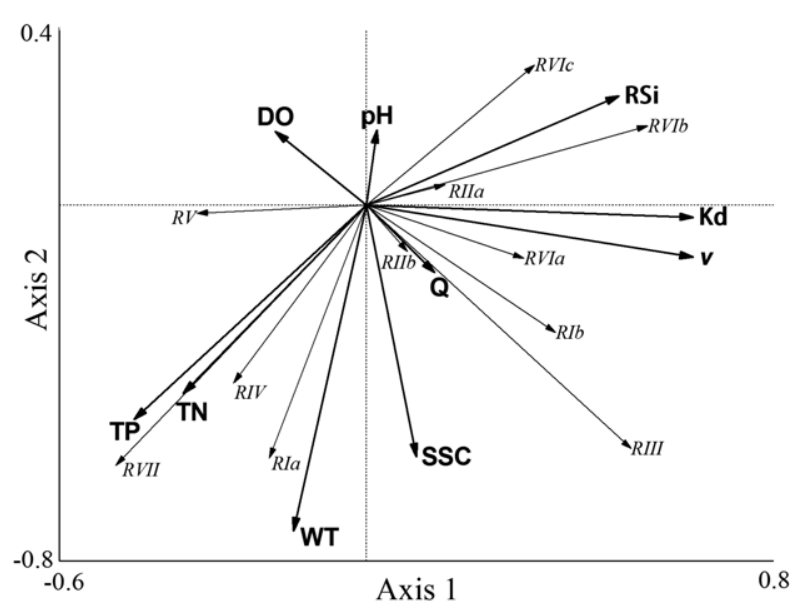

Fig. 1. Biplots of the RDA based on the biomass of the $M B F G_{R}$ and the environmental variables. WT, surface water temperature; $\mathrm{DO}$, dissolved oxygen; $\mathrm{K}_{\mathrm{d}}$, light attenuation coefficient; SSC, suspended sediment concentration; $\mathrm{Q}$, discharge; $v$, flow velocity; TN, total nitrogen; TP, total phosphorus; RSi, soluble reactive silicate. 
$\mathrm{MBFG}_{\mathrm{R}}$ with respect to the environmental variables. Groups RIa, RIV, and RVII were closely related to TN, TP, and WT. Groups RVIb and RVIc were closely related to RSi. Groups RIb RIII and RVIa were closely related to $\mathrm{Q}, v$, and SSC.

From 864 river cases, 245 presented that one $\mathrm{MBFG}_{\mathrm{R}}$ reached $>75 \%$ of the total biomass. Groups RIb and RIIa were dominant only in 6 and 8 river samples, respectively.
Group RIa dominated in 11 river samples, Group RIIb in 13, Group RIII in 26, Group RIV in 17, Group RV in 58, Group RVIa in 38, Group RVIb in 45, Group RVIc in 13, and Group RVII in 10. Subsequently, each river case was labelled according to the dominant $\mathrm{MBFG}_{\mathrm{R}}$ and was classified according to the environmental variables. The pruned tree had a complexity parameter of 0.01 , a relative error of 0.14 , and a cross-validated error of 0.87 .

Tab. 2. Description of the $\mathrm{MBFG}_{\mathrm{R}}$ obtained using more than 800 river samples.

\begin{tabular}{|c|c|c|c|c|c|c|c|c|c|c|c|c|}
\hline & & $\begin{array}{c}V \\
\left(\mu m^{3}\right)\end{array}$ & $\begin{array}{c}S \\
\left(\mu m^{2}\right)\end{array}$ & $\begin{array}{c}S / V \\
\left(\mu m^{-1}\right)\end{array}$ & $\begin{array}{l}\text { MLD } \\
(\mu \mathrm{m})\end{array}$ & Aer & Fla & Muc & Het & Si & Uni & Exs \\
\hline $\begin{array}{l}\text { RIa } \\
n=43\end{array}$ & & & $\begin{array}{c}124 \\
2.1-5.6 \mathrm{e}+3\end{array}$ & $\begin{array}{c}3.6 \\
1.0-10.4\end{array}$ & $\begin{array}{c}8.5 \\
0.7-31.7\end{array}$ & & $\begin{array}{c}0.00 \\
0\end{array}$ & & $\begin{array}{c}0.00 \\
0\end{array}$ & $\begin{array}{c}0.00 \\
0\end{array}$ & $\begin{array}{c}0.10 \\
0-1\end{array}$ & $\begin{array}{c}0.00 \\
0\end{array}$ \\
\hline $\begin{array}{l}\mathrm{RIb} \\
\mathrm{n}=29\end{array}$ & Small organisms with flagella & $\begin{array}{c}42.4 \\
0.8-283\end{array}$ & $\begin{array}{c}165 \\
5.8-7.6 \mathrm{e}+3\end{array}$ & $\begin{array}{c}5.2 \\
1.4-26.2\end{array}$ & $\begin{array}{c}20.1 \\
1.2-53.1\end{array}$ & $\begin{array}{c}0.00 \\
0\end{array}$ & $\begin{array}{c}1.00 \\
1\end{array}$ & & $\begin{array}{c}0.00 \\
0\end{array}$ & $\begin{array}{c}0.00 \\
0\end{array}$ & $\begin{array}{c}0.90 \\
0-1\end{array}$ & $\begin{array}{c}0.00 \\
0\end{array}$ \\
\hline & & $\begin{array}{c}487 \\
1.5-2.63+3\end{array}$ & $\begin{array}{c}248 \\
4.5-2.1 \mathrm{e}+3\end{array}$ & & & $\begin{array}{c}0.00 \\
0\end{array}$ & $\begin{array}{c}1.00 \\
1\end{array}$ & 0 & $\begin{array}{c}0.00 \\
0\end{array}$ & $\begin{array}{c}0.31 \\
0-1\end{array}$ & $\begin{array}{c}0.83 \\
0-1\end{array}$ & $\begin{array}{c}1.0 \\
1\end{array}$ \\
\hline & $\begin{array}{l}\text { Medium to large flagellated organisms } \\
\text { with exoskeletal structures }\end{array}$ & $\begin{array}{c}3.2 \mathrm{e}+3 \\
15.7-2.1 \mathrm{e}+5\end{array}$ & $\begin{array}{c}906 \\
6.7-2.3 \mathrm{e}+4\end{array}$ & $\begin{array}{c}1.4 \\
0.1-5.0\end{array}$ & $\begin{array}{c}18.5 \\
5.2-186\end{array}$ & $\begin{array}{c}0.00 \\
0\end{array}$ & $\begin{array}{c}1.00 \\
1\end{array}$ & $\begin{array}{c}0.00 \\
0\end{array}$ & $\begin{array}{c}0.00 \\
0\end{array}$ & $\begin{array}{c}0.12 \\
0-1\end{array}$ & $\begin{array}{c}0.75 \\
0-1\end{array}$ & $\begin{array}{c}1.00 \\
1\end{array}$ \\
\hline $\begin{array}{l}\mathrm{RIII} \\
\mathrm{n}=70\end{array}$ & Large filaments & $\begin{array}{c}2.9 \mathrm{e}+3 \\
6.2-1.7 \mathrm{e}+4\end{array}$ & $\begin{array}{c}2.9 \mathrm{e}+3 \\
18.5-8.53+3\end{array}$ & $\begin{array}{c}1.8 \\
0.4-4.8\end{array}$ & & $\begin{array}{c}0.63 \\
0-1\end{array}$ & $\begin{array}{c}0.00 \\
0\end{array}$ & & & $\begin{array}{c}0.00 \\
0\end{array}$ & $\begin{array}{c}0.00 \\
0\end{array}$ & $\begin{array}{c}0.00 \\
0\end{array}$ \\
\hline & & $\begin{array}{c}1.6 \mathrm{e}+3 \\
12.4-5.1 \mathrm{e}+4\end{array}$ & $\begin{array}{c}811 \\
28.6-1.9 \mathrm{e}+4\end{array}$ & $\begin{array}{c}1.6 \\
0.1-8.9\end{array}$ & & $\begin{array}{c}0.00 \\
0\end{array}$ & $\begin{array}{c}0.00 \\
0\end{array}$ & $\begin{array}{c}0.00 \\
0\end{array}$ & $\begin{array}{c}0.00 \\
0\end{array}$ & $\begin{array}{c}0.00 \\
0\end{array}$ & $\begin{array}{c}0.44 \\
0-1\end{array}$ & $\begin{array}{c}0.00 \\
0\end{array}$ \\
\hline $\begin{array}{l}\mathrm{RV} \\
\mathrm{n}=76\end{array}$ & $\begin{array}{l}\text { Unicellular flagellates of medium to } \\
\text { large size }\end{array}$ & $\begin{array}{c}1.2 \mathrm{e}+3 \\
4.6-1.0 \mathrm{e}+5\end{array}$ & $\begin{array}{c}655 \\
7.1-1.9 \mathrm{e}+4\end{array}$ & $\begin{array}{c}1.3 \\
0.1-4.7\end{array}$ & $\begin{array}{c}17.3 \\
6.1-203\end{array}$ & $\begin{array}{c}0.00 \\
0\end{array}$ & $\begin{array}{c}1.00 \\
1\end{array}$ & $\begin{array}{c}0.00 \\
0\end{array}$ & $\begin{array}{c}0.00 \\
0\end{array}$ & $\begin{array}{c}0.00 \\
0\end{array}$ & $\begin{array}{c}1.00 \\
1\end{array}$ & $\begin{array}{c}0.00 \\
0\end{array}$ \\
\hline $\begin{array}{l}\text { RVIa } \\
\mathrm{n}=87\end{array}$ & $\begin{array}{l}\text { Small non-flagellated organisms with } \\
\text { siliceous exoskeletons }\end{array}$ & $\begin{array}{c}311 \\
7.5-1.5 \mathrm{e}+3\end{array}$ & $\begin{array}{c}575 \\
3.4-2.4 \mathrm{e}+3 \\
\end{array}$ & $\begin{array}{c}1.2 \\
0.4-4.2\end{array}$ & $\begin{array}{c}21.8 \\
2.8-190\end{array}$ & $\begin{array}{c}0.00 \\
0\end{array}$ & $\begin{array}{c}0.00 \\
0\end{array}$ & $\begin{array}{c}0.00 \\
0\end{array}$ & $\begin{array}{c}0.00 \\
0\end{array}$ & $\begin{array}{c}1.00 \\
1\end{array}$ & $\begin{array}{c}1.00 \\
1\end{array}$ & $\begin{array}{c}1.00 \\
1\end{array}$ \\
\hline $\begin{array}{l}\mathrm{RVIb} \\
\mathrm{n}=53\end{array}$ & $\begin{array}{l}\text { Large non-flagellated organisms with } \\
\text { siliceous exoskeletons }\end{array}$ & $\begin{array}{c}4.6 \mathrm{e}+3 \\
11.9-6.4 \mathrm{e}+4\end{array}$ & $\begin{array}{c}1.6 \mathrm{e}+3 \\
16.4-2.1 \mathrm{e}+4\end{array}$ & $\begin{array}{c}1.1 \\
0.2-3.2\end{array}$ & $\begin{array}{c}53.2 \\
10.3-610\end{array}$ & $\begin{array}{c}0.00 \\
0\end{array}$ & $\begin{array}{c}0.00 \\
0\end{array}$ & $\begin{array}{c}0.00 \\
0\end{array}$ & $\begin{array}{c}0.00 \\
0\end{array}$ & $\begin{array}{c}1.00 \\
1\end{array}$ & $\begin{array}{c}1.00 \\
1\end{array}$ & $\begin{array}{c}1.00 \\
1\end{array}$ \\
\hline $\begin{array}{l}\mathrm{RVIc} \\
\mathrm{n}=47\end{array}$ & $\begin{array}{l}\text { Colonial non-flagellated organisms with } \\
\text { siliceous exoskeletons }\end{array}$ & $\begin{array}{c}1.4 \mathrm{e}+3 \\
8.1-5.4 \mathrm{e}+4\end{array}$ & $\begin{array}{c}1.2 \mathrm{e}+3 \\
10.5-1.9 \mathrm{e}+4\end{array}$ & $\begin{array}{c}1.1 \\
0.1-3.5\end{array}$ & $\begin{array}{c}40.6 \\
5.4-362\end{array}$ & $\begin{array}{c}0.00 \\
0\end{array}$ & $\begin{array}{c}0.00 \\
0\end{array}$ & $\begin{array}{c}0.00 \\
0\end{array}$ & $\begin{array}{c}0.00 \\
0\end{array}$ & $\begin{array}{c}1.00 \\
1\end{array}$ & $\begin{array}{c}0.00 \\
0\end{array}$ & $\begin{array}{c}1.00 \\
1\end{array}$ \\
\hline $\begin{array}{l}\mathrm{RVII} \\
\mathrm{n}=41\end{array}$ & Large mucilaginous colonies & $\begin{array}{c}2.5 \mathrm{e}+4 \\
4.3-1.3 \mathrm{e}+4\end{array}$ & $\begin{array}{c}2.2 \mathrm{e}+3 \\
15.2-4.6 \mathrm{e}+4\end{array}$ & $\begin{array}{c}1.0 \\
0-5.6\end{array}$ & $\begin{array}{c}21.3 \\
3.5-244\end{array}$ & $\begin{array}{c}0.15 \\
0-1\end{array}$ & $\begin{array}{c}0.00 \\
0\end{array}$ & $\begin{array}{c}1.00 \\
1\end{array}$ & $\begin{array}{c}0.00 \\
0\end{array}$ & $\begin{array}{c}0.00 \\
0\end{array}$ & $\begin{array}{c}0.00 \\
0\end{array}$ & 0.00 \\
\hline
\end{tabular}

$V$, volume; $S$, surface area; $M L D$, maximum linear dimension.

Tab. 3. Representative taxa of $M_{B F G}$.

\begin{tabular}{|c|c|c|}
\hline $\mathrm{MBFG}_{\mathrm{R}}$ & Description & Representative taxa \\
\hline RIa & Small organisms & $\begin{array}{l}\text { Synechocystis minuscula, Scenedesmus ellipticus, } \\
\text { Chroococcus cohaerens, Stichococcus bacillaris }\end{array}$ \\
\hline RIb & Small organisms with flagella & Chroomonas spp. \\
\hline RIIa & Small flagellated organisms with exoskeletal structures & Kephyrion spp. Chrysococcus spp. Chrysosphaerella spp. \\
\hline RIIb & Medium to large flagellated organisms with exoskeletal structures & Peridinium spp. Peridiniopsis spp. \\
\hline RIII & Large filaments & Osillatoriales, Nostocales, Ulothrix spp. \\
\hline RIV & Medium sized organisms lacking specialized traits & Volvocales, ${ }^{*}$ Chlorococcales, Desmidiaceae \\
\hline RV & Unicellular flagellates of medium to large sizes & Cryptomonas spp. Euglena spp. Gymnodinium spp. \\
\hline RVIa & Small non-flagellated organisms with siliceous exoskeletons & $\begin{array}{l}\text { Cyclotella spp. Navicula minima, Gomphonema parbulum, } \\
\text { Cymbella pusilla }\end{array}$ \\
\hline RVIb & Large non-flagellated organisms with siliceous exoskeletons & Pinnularia gentilis, Stephanodiscus neoastraea, Cymbella cistula \\
\hline RVIc & Colonial non-flagellated organisms with siliceous exoskeletons & Melosira spp. Asterionella formosa, Asterionella spp. \\
\hline RVII & Large mucilaginous colonies & Microcystis spp. Botryococcus braunii \\
\hline
\end{tabular}


Rivers dominated by all groups were adequately discriminated according to the environmental variables by the tree (Fig. 2). $K_{d}$ was the first selected variable with a threshold value of $4.5 \mathrm{~m}^{-1}$ in the first node (the root node). The next selected variable was WT, but the threshold values were not the same to the left $\left(22^{\circ} \mathrm{C}\right)$ and to the right $\left(20^{\circ} \mathrm{C}\right)$. The further selected variables included $v, \mathrm{SSC}$ and RSi. Meanwhile, TP, TN, pH, DO, and Q were not important based on the analysis. The threshold values of environmental conditions could divide most cases dominated by different groups, though the division was not $100 \%$ accurate.

\section{Potential links between $\mathrm{MBFG}_{\mathrm{R}}$ and the zooplankton and river types}

A total of 36 zooplankton genera were collected, among which 5 copepod, 13 Cladocera, and 18 Rotifera species were included. The individual core body length ranged from 50 to $2850 \mu \mathrm{m}$. Based on the probability distribution, zooplankton could be categorized into three groups: small, medium, and large (Fig. 3). The upper 5\% of events was designated as large zooplankton (length $>1000 \mu \mathrm{m}$ ), the bottom $65 \%$ as small (length $>330 \mu \mathrm{m}$ ), and the remainder as medium zooplankton $(330<$ length $<1000 \mu \mathrm{m})$.

Correlation coefficients between the biomass of $\mathrm{MBFG}_{\mathrm{R}}$ dominant group and the density of zooplankton showed the significant relationships of potamoplankton and predator taxa and size. Group RIa was related to small, medium, and total zooplankton. Groups RIb and RIV showed relationship with medium and large zooplankton. Group RIIa showed a significant correlation with total zooplankton. Groups RIII and RVIc were positively correlated with copepods. Group RVIa was related to small and medium zooplankton especially rotifers. Group RVII was negatively correlated with the total zooplankton. Groups RIIb, RV, and RVIb showed nearly no correlation with any zooplankton. The synoptic correla- tion matrix between dominant $\mathrm{MBFG}_{\mathrm{R}}$ biomass and the abundance of zooplankton is reported in Tab. 5. A scatter diagram of zooplankton and potamoplankton is reported in Supplementary Fig.1.

Fig. 4 shows the positioning of all river-samples with $>95 \%$ dominance of a $\mathrm{MBFG}_{\mathrm{R}}$ within the framework of the Gasol model (Gasol, 1994). According to this model, Groups RIa, RIII, RVIc, and RVII purely dominated in bottom-up system, whereas only Group RVIa dominated

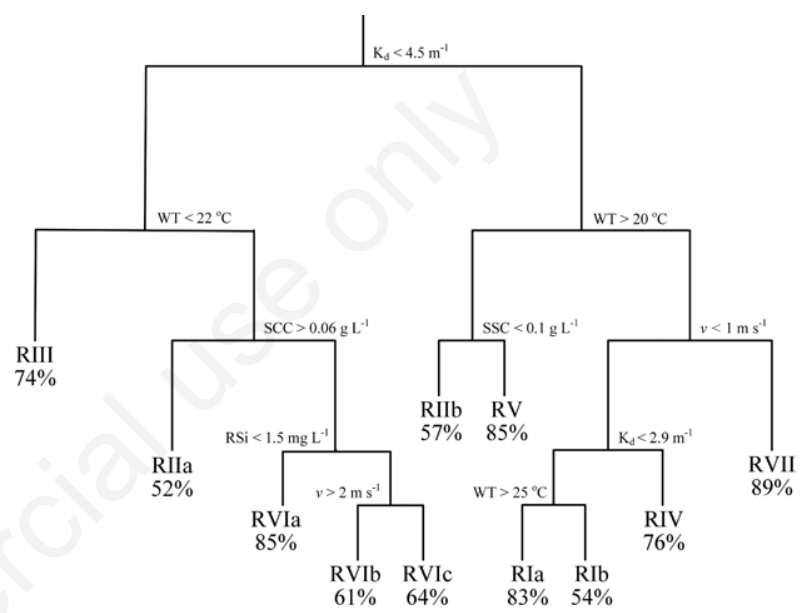

Fig. 2. Classification tree of the environmental variables explaining the dominance ( $75 \%$ over total biomass) of $\mathrm{MBFG}_{\mathrm{R}}$. The environmental variable and the corresponding threshold value are shown for each node. At the end of each branch, the $\mathrm{MBFG}_{\mathrm{R}}$ with more cases is included as the decisive factor. The percentage representing the proportion of cases where a specific $M B F G_{R}$ was dominant is shown below each group. $\mathrm{K}_{\mathrm{d}}$, light attenuation coefficient; $v$, flow velocity; WT, surface water temperature; RS, reactive silicate; SSC, suspended sediment concentration.

Tab. 4. Key for classifying phytoplankton under the $\mathrm{MBFG}_{\mathrm{R}}$ approach.

\begin{tabular}{|c|c|c|c|c|c|}
\hline \multirow[t]{2}{*}{ Presence of flagella } & Presence of hard exoskeletal structures & $\begin{array}{l}\mathrm{V}<300 \mu \mathrm{m}^{3} \\
\mathrm{~V}>300 \mu \mathrm{m}^{3}\end{array}$ & \multicolumn{3}{|l|}{ Group RIIa } \\
\hline & Absence of hard exoskeletal structures & $\begin{array}{l}\text { MLD }<10 \mu \mathrm{m} \\
\text { MLD }>10 \mu \mathrm{m} \\
\text { Colony }\end{array}$ & $\begin{array}{l}\text { Group RIb } \\
\text { Group RV } \\
\text { Group RIV }\end{array}$ & & \\
\hline Absence of flagella & Presence of siliceous structures & $\begin{array}{l}\text { Unicell } \\
\text { Colony }\end{array}$ & $\begin{array}{l}\mathrm{V}<300 \mu \mathrm{m}^{3} \\
\mathrm{~V}>300 \mu \mathrm{m}^{3} \\
\text { Group RVIc }\end{array}$ & $\begin{array}{l}\text { Group RVIa } \\
\text { Group RVIb }\end{array}$ & \\
\hline & Absence of siliceous structures & $\begin{array}{l}\text { Unicell } \\
\text { Filaments }\end{array}$ & $\begin{array}{l}\text { Group RIV } \\
\text { Length }<20 \mu \mathrm{m} \\
\text { Length }>20 \mu \mathrm{m}\end{array}$ & $\begin{array}{l}\text { Group RIa } \\
\text { Group RIII }\end{array}$ & \\
\hline & & Colony & $\begin{array}{l}\text { Absence of mucilage } \\
\text { Presence of mucilage }\end{array}$ & $\begin{array}{l}\mathrm{MLD}<20 \mu \mathrm{m} \\
\mathrm{MLD}>20 \mu \mathrm{m} \\
\mathrm{MLD}<20 \mu \mathrm{m} \\
\mathrm{MLD}>20 \mu \mathrm{m}\end{array}$ & $\begin{array}{l}\text { Group RIa } \\
\text { Group RIV } \\
\text { Group RIa } \\
\text { Group RVII }\end{array}$ \\
\hline
\end{tabular}


in top-down regulation. Other groups dominated with both kinds of potamoplankton-zooplankton links. The distribution of $\mathrm{MBFG}_{\mathrm{R}}$ dominance ( $>75 \%$ cases) in different river types (Tab. 6) showed the significance of topography, stream order, and river sections for Groups RIb, RIII, RV, RVIa, RVIc, and RVII. Group RIb preferred the middle-upper section of higher rivers in mountainous areas. Group RIII preferred the middle-down section of lower rivers. Group RV and RVII preferred the middle-down section of lower rivers in plain. Group RVIa and RVIc preferred middle-downstream in plains. Meanwhile, the other groups (RIa, RIIa, RIIb, RIV, and RVIb) seemed uncorrelated to river type.

\section{DISCUSSION}

The concept of using easily determined morphological criteria as an indicators of functional properties may be applied to potamoplankton in rivers just as they are applied to phytoplankton in lakes. The $\mathrm{MBFG}_{\mathrm{R}}$ well reflected the different habitat templates. The main ecological processes in lakes are usually evasion of loss processes (mixing and zooplankton), water temperature conditions, and resources acquisition (nutrients and light) (Kruk and Segura, 2012). In addition to these processes, the unique effect from river flow was also represented in the results.

For applying the model, as described by Kruk and Segura (2012), a classification tree was constructed to compare the specific environmental thresholds that determine the dominance of a group in rivers. Most of the groupdominated river cases were successfully separated according to the environmental variables. By eliminating two important factors in RDA analysis (TP and TN), the CART characterized external forces according to five indicators $\left(\mathrm{K}_{\mathrm{d}}, \mathrm{WT}, v, \mathrm{SCC}\right.$, and $\left.\mathrm{RSi}\right)$ and developed habitat templates for the eleven groups (Fig. 2). In contrast to the previous MBFG findings (Kruk and Segura, 2012), the $\mathrm{MBFG}_{\mathrm{R}}$ model emphasized the importance of flow velocity and suspended sediment. These results showed that the dominance of potamoplankton functional groups depends first on hydrological conditions and second on nutrients. Discharge was not selected which seemed to be counterintuitive. This decision might have been caused by a redundancy of the variables, which were based on long term statistics and not exactly equivalent to that potamoplankton species experienced in nature. In the following Subsections, we describe in detail the morphological characteristics and habitat template of each group, as well as their relationship with zooplankton predation and river types.

\section{Groups RIa and RIb: flagella cause notable differences in small organisms}

These r-selected representatives, in which small size and high growth rate were aligned together in MBFG I
(Kruk et al., 2010); they increased with the total nutrients and dominated in dynamic ecosystems (Kruk and Segura, 2012). However, this description might be too general in riverine systems because $\mathrm{MBFG}_{\mathrm{R}}$ discovered it was Group RIa without flagella that were strongly associated to nutrients. By contrast, it was flagellated Group RIb that could dominate under a wide variety of trophic conditions involving flushed and transitional systems (Fig. 1), especially the middle-upper stream in mountains (Tab. 6). Furthermore, the following differences were also indicated by the presence or absence of flagella: i) Group RIa had a dominant preference for warm environments (WT $>25^{\circ} \mathrm{C}$, Fig. 2), which could be a prerequisite to maintaining a high specific growth rate. Meanwhile, Group RIb could dominate at $20-25^{\circ} \mathrm{C}$ because their flagella-driven allowed for

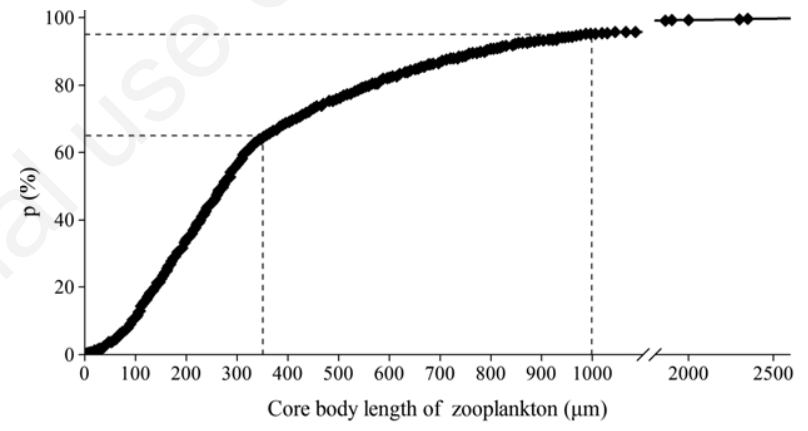

Fig. 3. Probability distribution (P) of zooplankton individual core body length. Dashed lines indicate the division of small, medium, and large predators.

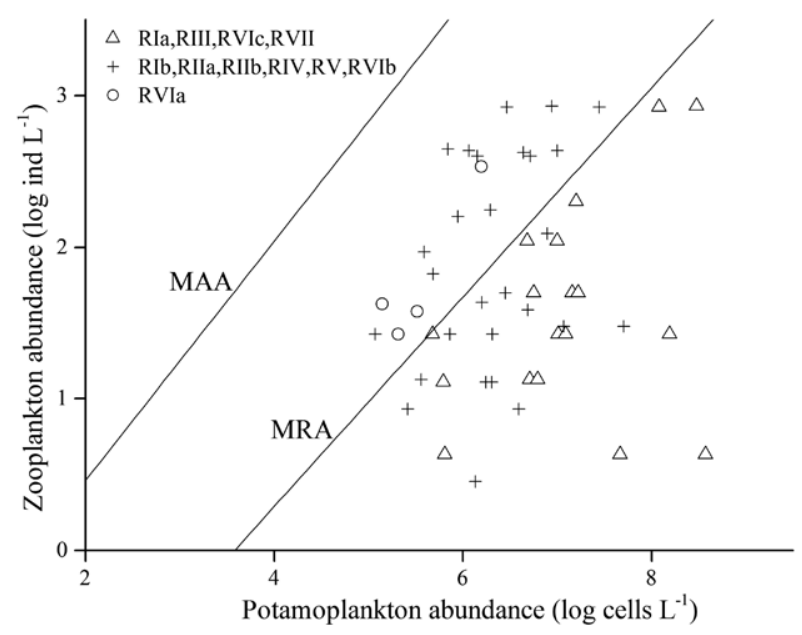

Fig. 4. Position of the river-cases where a specific $M B F G_{R}$ was dominant ( $90 \%$ over total biomass) within the framework of Gasol's model. MAA, maximum attainable abundance line; MRA, mean realized abundance line. 
better resource and nutrient acquisition (Reynolds, 1997). ii) Group RIa were possibly better food for small and medium zooplankton (Tab. 5) and only dominated under bottom-up control (Fig. 4). However, the presence of flagella increased the maximum linear dimension of Group $\mathrm{RIb}$, thereby allowing the species from this group to escape from small invertebrate predators with strict limitations on prey size and shape (Do and On, 1974); the presence of flagella greatly amplified the effect of water viscosity and flow ability on phytoplankton movement, thereby making it difficult for small zooplankton individuals bite or drag (Boukal, 2014). Although predators generally select sizematched prey (Brose et al., 2006), Group RIb species with small sizes were available for large zooplankton (Tab. 5), and the risk is especially high when species from this group are abundant (Van Donk et al., 2011). Our data-set was composed of a low number of rivers dominated by Group RIb (only 6 samples), which precluded further analysis of their dominance.

\section{Groups RIIa and RIIb: coexistence of flagella and exoskeletal structures}

According to the description by Kruk and Segura (2012), Group RIIa was closer to MBFG II: small flagellates which have exoskeletal structures and favor cold oligotrophic conditions. Most species in RIIb belonged to MBFG V which had the typical flagella and large size (e.g., Ceratium hirundinella). But Group RIIb appeared closer to Group RIIa in the RDA biplots, thereby indicat-

Tab. 5. Correlation coefficients of dominant $\mathrm{MBFG}_{\mathrm{R}}$ biomass (dominance $>75 \%$ ) and zooplankton abundance $(\mathrm{P}<0.001)$.

\begin{tabular}{|c|c|c|c|c|c|c|c|c|}
\hline $\mathrm{MBFG}_{\mathrm{R}}$ & No. of samples & $\begin{array}{c}\text { Total } \\
\text { zooplankton }\end{array}$ & Rotifera & Cladocera & Copepoda & $\begin{array}{l}\text { Small } \\
\text { zooplankton }\end{array}$ & $\begin{array}{c}\text { Medium } \\
\text { zooplankton }\end{array}$ & $\begin{array}{c}\text { Large } \\
\text { zooplankton }\end{array}$ \\
\hline RIa & 11 & 0.60 & & & $\Delta=$ & 0.62 & 0.54 & \\
\hline $\mathrm{RIb}$ & 6 & & & & 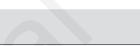 & & 0.66 & 0.60 \\
\hline RIIa & 8 & 0.84 & & & $0^{3}$ & & & \\
\hline RIIb & 13 & & & & reng & & & \\
\hline RIII & 26 & & & & 0.78 & & & \\
\hline RIV & 17 & & & & & & 0.74 & 0.51 \\
\hline $\mathrm{RV}$ & 58 & & & 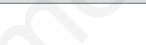 & & & & \\
\hline RVIa & 38 & & 0.61 & +8 & & 0.59 & 0.51 & \\
\hline RVIb & 45 & & & 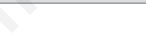 & & & & \\
\hline RVIc & 13 & & $\mathrm{~B}$ & & 0.67 & & & \\
\hline RVII & 10 & -0.82 & (l) & & & & & \\
\hline
\end{tabular}

The categories of individual core body length of zooplankton are defined as follows: small $<330 \mu \mathrm{m} ; 330<$ medium $<1000 \mu \mathrm{m} ;$ large $>1000 \mu \mathrm{m}$. Leastsquares linear regression lines are shown in the Supplementary Fig. 1.

Tab. 6. Distribution of $\mathrm{MBFG}_{\mathrm{R}}$ dominance ( $>75 \%$ cases) in different river types based on topography, scale (indicated by the drainage area of whole river), stream order, and section.

\begin{tabular}{|c|c|c|c|c|c|c|c|c|}
\hline \multirow[t]{2}{*}{$\mathrm{MBFG}_{\mathrm{R}}$} & \multicolumn{2}{|c|}{ Topography } & \multicolumn{2}{|c|}{ Drainage area $\left(\mathrm{km}^{2}\right)$} & \multicolumn{2}{|c|}{ Stream order } & \multicolumn{2}{|c|}{ River section } \\
\hline & Mountainous & Plain & $>5 \mathrm{e}+4$ & $<5 \mathrm{e}+4$ & $1-3$ & 4-6 & Middle-upper & Middle-down \\
\hline Sampled rivers & $\underline{33}$ & $\underline{68}$ & $\underline{36}$ & $\underline{65}$ & 61 & $\underline{40}$ & 29 & $\underline{72}$ \\
\hline RIa & $3 / 11$ & $8 / 11$ & $4 / 11$ & $7 / 11$ & $4 / 11$ & $7 / 11$ & $5 / 11$ & $6 / 11$ \\
\hline RIb & $6 / 6^{*}$ & $0 / 6$ & $2 / 6$ & $4 / 6$ & $1 / 6$ & $5 / 6^{*}$ & $5 / 6^{*}$ & $1 / 6$ \\
\hline RIIa & $4 / 8$ & $4 / 8$ & $2 / 8$ & $6 / 8$ & $2 / 8$ & $6 / 8$ & $5 / 8$ & $3 / 8$ \\
\hline RIIb & $5 / 13$ & $8 / 13$ & $4 / 13$ & $9 / 13$ & $7 / 13$ & $6 / 13$ & $3 / 13$ & $10 / 13$ \\
\hline RIII & $10 / 26$ & $16 / 26$ & $8 / 26$ & $18 / 26$ & $24 / 26^{*}$ & $2 / 26$ & $3 / 26$ & $23 / 26^{*}$ \\
\hline RIV & $8 / 17$ & $9 / 17$ & $9 / 17$ & $8 / 17$ & $10 / 17$ & $7 / 17$ & $8 / 17$ & $9 / 17$ \\
\hline RV & $4 / 58$ & $54 / 58^{*}$ & $20 / 58$ & $38 / 58$ & $48 / 58^{*}$ & $10 / 58$ & $3 / 58$ & $55 / 58^{*}$ \\
\hline RVIa & $3 / 38$ & $35 / 38^{*}$ & $10 / 38$ & $28 / 38$ & $22 / 38$ & $16 / 38$ & $4 / 38$ & $34 / 38^{*}$ \\
\hline RVIb & $24 / 45$ & $21 / 45$ & $25 / 45$ & $20 / 45$ & $30 / 45$ & $15 / 45$ & $22 / 45$ & $23 / 45$ \\
\hline RVIc & $2 / 13$ & $11 / 13^{*}$ & $5 / 13$ & $8 / 13$ & $8 / 13$ & $5 / 13$ & $1 / 13$ & $12 / 13^{*}$ \\
\hline RVII & $1 / 10$ & $9 / 10^{*}$ & $4 / 10$ & $6 / 10$ & $8 / 10^{*}$ & $2 / 10$ & $2 / 10$ & $8 / 10$ \\
\hline
\end{tabular}

*The underlined numbers indicate the total number of studied rivers; * significant $M B F G_{R}$ dominance in the river types $(P<0.05)$. 
ing that they shared favorable environments; this trend was probably caused by the coexistence of flagella and exoskeletal structures as important morphological traits. First, Groups RIIa and RIIb both could withstand some flushes and impacts under the protection of hard exoskeletal structures. Second, they both benefited from the effective nutrient foraging and permitted mixotrophy (Salmaso and Padisák, 2007), which increased their adaptability to lower trophic levels (Kruk and Segura, 2012). However, Group RIIb showed no relationship with any zooplankton (Tab. 5), which might be an indicator of substantial grazing tolerance (in accordance with the results of Kruk and Segura, 2012). Besides physical defence, some species in Group RIIb could release chemicals upon mechanical damage (e.g., Alexandrium minutum). Chemical cues associated with the risk of herbivory allowed for resistance to further zooplankton grazing and potentially affected fertilization success or embryonic fitness (Van Donk et $a l ., 2011)$. The key distinction of Groups RIIa and RIIb was sinking loss. For RIIa, the so-called exoskeletal structures of some species were in the form of scales and/or spines that just covered part of the cell body, thereby extremely reducing the side effects of heavy structures. The small size of species in this group and the presence of flagella facilitated buoyancy, especially in rivers. Meanwhile, the large size and teardrop shape of species in Group RIIb worsened the sinking problem (Padisák et al., 2003). Therefore, the dominance of Group RIIb was not achieved in turbulent environments with $\mathrm{K}_{\mathrm{d}}>4.5 \mathrm{~m}^{-1}$.

\section{Group RIII: large filaments}

MBFG III was composed of large filaments with aerotopes, which confer greater tolerance to limited light and nutrients (Kruk et al., 2010; Kruk and Segura, 2012). Group RIII in $\mathrm{MBFG}_{\mathrm{R}}$ included absorbed species of similar morphology, even those without aerotopes, and were located closely related to environmental variables concerning hydrology (Q, v, and SCC) in the RDA biplots (Fig. 1). Their probable key to success in rivers was the flexibility of filamentous life forms instead of the buoyancy from aerotopes. Filamentous algae, whether possessing aerotopes (e.g., Planktothrix agardhii) or otherwise (e.g., Anabaenopsis circularis), were important and common in potamoplankton communities; these algae often dominated in the middledown stream of lower rivers (Tab. 6). Similar to MBFG III, Group RIII could dominate in low-light environments, but only at $\mathrm{WT}>22^{\circ} \mathrm{C}$ (Fig. 2). The high optimum temperature seemed to be another preferred condition, which was not seriously considered as a threshold of dominance for this group (Kruk and Segura, 2012). Their large size, occasionally coiled shape, and potential toxicity (Kruk et al., 2010) increased resistance to grazing. Group RIII only had a close relationship with copepods according to the results (Tab. 5). Besides the matched sizes, copepods showed a high de- gree of feeding selection by maximizing the ingestion of the most nutritious food from a mixture of particles by using algae secondary metabolites as detection cues to prevent toxin ingestion (Koski et al., 2002). Consequently, selective feeding usually allows copepods to uninhibitedly feed on alternative food in the presence of toxic species, thereby resulting in grazers coexisting with blooms (Ger et al., 2014).

\section{Group RIV: medium sized organisms lacking specialized traits}

The composition and characteristics of this group were basically similar in MBFG and $\mathrm{MBFG}_{\mathrm{R}}$. As high quality food, this group contained the most varied species and shapes which covered a spectrum from typically r-selected and K-selected types (Kruk et al., 2010). In accordance with the habitat template of MBFG IV, Group RIV was liable to high light. However, no evidence was observed in the river cases supporting low nutrient and temperature conditions (Figs. 1 and 2). Both Group RIV and MBFG IV included coenobium, which comprised many flagellated cells (e.g., Pandorina morum), that cannot reach high unidirectional speed because of the unsynchronized flagellar movement of individual cells in the colony is not synchronized (Padisák et al., 2003). In this way, the functions (e.g., motility and flotation) of morphological variability (e.g., shapes, spines, and protuberances) that were observed among cells in the colony were most likely handicapped by cybotactic life forms. This phenomenon seemed to be an ecological cost of grazing resistance. Small zooplankton did not show an obvious correlation with the biomass of Group RIV (Tab. 5) probably because of algal colony formation and size, which were influenced by chemicals released by predators (Van Donk et al., 2011).

\section{Group RV: unicellular flagellates of medium to large sizes}

In $\mathrm{MBFG}_{\mathrm{R}}$, Group RV was an aggregation of Cryptophyceae, Euglenophyceae, Volvocales and Chlorococcales, and excluded Dinophyceae (with exoskeletal structures). This group matched the characteristics described for MBFG V, as follows: good motility, preference for low temperature (WT $<20^{\circ} \mathrm{C}$, Fig. 2), and substantial tolerance to grazing (Tab. 5). However, two points are worthy of discussion. First, MBFG V mixed species of Groups RV and RIIb by ignoring the absence and presence of exoskeletal structures, whereas this morphological difference might lead to observable discrepancies in terms of tolerance to suspended sediment in rivers. Potamoplankton showed sensitivity to inorganic (non-algal) turbidity, which is a function of SSC (May et al., 2003). Group RV was possibly vulnerable to high SSC because it lacked hard armour (e.g., dinoflagellates) (Lau et al., 
2007 ) to protect against the direct physical impact of suspended sediment along with the current; thus, this group dominated in the middle-down stream of plain lower rivers (Tab. 6) with only SSC $<0.1 \mathrm{~g} \mathrm{~L}^{-1}$ (Fig. 2). Second, MBFG V achieved dominance at high $\mathrm{K}_{\mathrm{d}}\left(>3.9 \mathrm{~m}^{-1}\right)$ whereas Group RV required $\mathrm{K}_{\mathrm{d}}<4.5 \mathrm{~m}^{-1}$. These results might be a reflection of the hydrological differences between rivers and lakes. In river systems, the light attenuation coefficient can be influenced by turbulence, basin morphology and tripton (Phlips et al., 2000; Christian and Sheng, 2003). Group RV largely preferred the slight effects from slow flow with little amounts of sediment, as indicated by the low $\mathrm{K}_{\mathrm{d}}$.

\section{Groups RVIa, RVIb, and RVIc: non-flagellated organisms with siliceous exoskeletons}

The obligate presence of a siliceous wall was probably the main constraining trait of species from these groups (Kruk et al., 2010). MBFG VI collected all diatoms, thereby indicating their special common characteristics, as follows: immobility, silicate requirement, preference for low temperature, and resistance to viral infection (Kruk and Segura, 2012). $\mathrm{MBFG}_{\mathrm{R}}$ exerted a high amount of stress on the individual volume and life forms, which subdivided them into three groups.

Group RVIa mainly composed of small unicellular diatoms. The small size weakened the effect of the high exoskeleton density on sinking loss, and reduced the silicate requirements for reproduction ( $\mathrm{RSi}<1.5 \mathrm{mg} \mathrm{L}^{-1}$; Figs. 1 and 2). Correspondingly, Group RVIa was easily grazed by rotifers and other small or medium sized zooplankton (Tab. 5). However, this group was the only group that could dominate the middle-down stream of plain rivers (Tab. 6) under top-down control (Fig. 4) largely due to their high growth rate (e.g., Cyclotella meneghiniana).

Group RVIb mainly represented large unicellular diatoms. According to their morphology, this group had hiah aptitude for high flow velocity $\left(v>2 \mathrm{~m} \mathrm{~s}^{-1}\right)$ in turbulent environments. Their relatively high maximum linear dimension might give substantial tolerance to grazing, but their large size increased sinking. In addition, grazing-induced silicification (e.g., Fragilariopsis kerguelensis) might increase the mechanical resistance of the diatom (not limited to species of this group) frustule (Hamm et al., 2003). To date, the chemical compound that induces this defence mechanism remains unknown.

Group RVIc mainly represented colonial diatoms. The formation of a colony was greatly induced by heavy walls (Padisák et al., 2003). Some species have been shown to be readily ingested by zooplankton taxa (e.g., copepods; Tab. 5), but survived gut passage when arranged as chains following ingestion by predators (Van Donk et al., 2011). The advantages of this life form included defences to grazing and the reduction of sinking loss (Padisák et al.,
2003). However, the formation of colonies negatively affected photosynthesis and the uptake of nutrients because it reduced the available surface-per-volume (Verschoor et al., 2009). Consequently, colonial diatoms preferred the middle-down stream of plain rivers (Tab. 6) and seldom dominated turbulent current $\left(v>2 \mathrm{~m} \mathrm{~s}^{-1}\right.$, Fig. 2). The fragmentation of diatom colonies would occur with the beginning of population decline, during which these colonies usually split and sink into the hypolimnion to allow new development (Padisák et al., 2003).

\section{Group RVII: large mucilaginous colonies}

Group RVII in $\mathrm{MBFG}_{\mathrm{R}}$ matched the composition and characteristics of MBFG VII. The presence of mucilage provided buoyant properties, grazing avoidance, and sensitivity to low resource supply (Kruk and Segura, 2012). This group tended to dominate rivers with low $\mathrm{K}_{\mathrm{d}}\left(<4.5 \mathrm{~m}^{-1}\right)$ and slow flow $\left(v<1 \mathrm{~m} \mathrm{~s}^{-1}\right)$ in warm seasons $\left(\mathrm{WT}>20^{\circ} \mathrm{C}\right.$ ) like the middle-down stream of plain lower rivers (Tab. 6). Closely linked to TP and TN (Fig. 1), the massive occurrence of Group RVII might indicate an out-of-balance state in the ecosystem, which was mainly due to eutrophication. Uniquely, the biomass of this group was negatively related to the total zooplankton density (Tab. 5) under bottom-up control (Fig. 4) in rivers, which was obviously an evidence of toxic defences in phytoplankton species. Previously, Van Donk et al. (2011) demonstrated that several strains (e.g., Microcystis) increase their toxin production in response to direct and indirect exposure to herbivorous zooplankton. Some species of copepods and Cladocera can maximize adaptation via selective feeding or detoxification mechanisms (Ger et al., 2014). However, zooplankton taxa with detoxification mechanisms are challenged by the limited ability to handle individual food particles (e.g., Daphnia) (Ger et al., 2014) or the metabolic cost of maturing at a slower rate (e.g., Boeckella) (Twombly et al., 1998). Apparently, neither existing predators nor their future evolved forms would actually use phytoplankton of this group for food (Ger et al., 2014).

\section{Limitations of the $\mathrm{MBFG}_{\mathrm{R}}$ study}

The veracity and completeness of data are crucial to the study of potamoplankton. The establishment of $\mathrm{MBFG}_{\mathrm{R}}$ was purely based on field sampling, thereby leaving much to consider: i) the physical and chemical conditions at the point of sampling will not necessarily reflect the conditions created by river variability that have affected the phytoplankton; ii) riverine phytoplankton is actually a mixture of various planktonic elements that arrive from different water types of the watershed, such as shallows (Stoyneva, 1994), inflows (Istvànovic and Honti, 2011), and reservoirs. Therefore, the potamoplankton composition frequently reflects the effects of the key 
processes in the watershed and not just those that act in the main channel of the river; this is especially true for highly modified watersheds; iii) more frequent sampling in some rivers might cause pseudo-replication, especially in cases with small differences in the hydrological characteristics of sampling periods.

These limitations are impossible to eliminate thoroughly when field sampling is conducted across wide areas. Thus, highly manipulative laboratory experiments would be valuable as an additional complement.

\section{CONCLUSIONS}

The characteristics and habitat templates of all groups of $\mathrm{MBFG}_{\mathrm{R}}$ in terms of biomass distribution among rivers was described in this study and presented in Tab. 7. The conditions for significant dominance of most groups (RIa, RIIb, RIII, RIV, RV, RVIa, RVIb, RVIc and RVII) were well discriminated by the environmental variables and constituted homogeneous groups. Compared with previous studies on lakes, the separation of Group RIb from Group RIa in MBFG I revealed their differences in terms of optimum temperature, predator composition and favourable river types. The separation of Group RIIb from MBFG V showed the importance of armour, as well as adaptability to flushing, turbulence, and suspended sediment. The different sizes and life forms (unicell or colony) divided the diatoms belonging to MBFG VI into several groups, as follows: Group RVIa (small size), Group RVIb (large size), and Group RVIc (colony). This subdivision revealed that only Group RVIa had low-silicate requirements and were grazed by most zooplankton. Group RVIb experienced high sinking loss. Group RVIc preferred the downstream regions of plain rivers, which were charac- terized by slow flow. However, the discriminatory power of the conditions was low for the dominance of Groups $\mathrm{RIb}$ and RIIa. Rivers in various geographical conditions and extreme environments should be included to improve the results presented here.

The $\mathrm{MBFG}_{\mathrm{R}}$ might fit potamoplankton classification better because of the following reasons: i) it did not mix species with and without flagella in any group; ii) it refined the classification of diatoms; iii) it included the various exoskeletons; iv) it disregarded the aerotopes of filaments.

These alterations are possibly reasonable: i) The rotation of flagella can move algae (Wetzel, 2001) to allow them to actively regulate their position (Fraisse et al., 2013). Motility may help phytoplankton find more favourable light and nutrient conditions in heterogeneous environments. ii) Diatoms are the primary components of potamoplankton communities. When more groups of this class are present, the classification approach for rivers can attain higher sensitivity. Individual volume and life forms (unicellular or colony) are major explanatory variables that should be given priority. iii) The exoskeletal structures of phytoplankton can greatly affect survival in rivers. Although the weight of these structures leads to increased sinking loss, their hardness effectively prevents phytoplankton from damage in turbulent flow (Lau et al., 2007). iv) The crucial advantage of large filaments in rivers is probably more related to flexibility rather than buoyancy. The importance of aerotopes, which reduce sinking loss, may be more evident in still water columns of lakes rather than river ecosystems.

In conclusion, a large data set from riverine ecosystems was used to verify that morphological traits instead of phytosociological traits would better represent the functional

Tab. 7. Summary of the $\mathrm{MBFG}_{\mathrm{R}}$ habitat templates.

\begin{tabular}{|c|c|c|c|c|c|c|c|c|}
\hline $\mathrm{MBFG}_{\mathrm{R}}$ & Compare to MBFG & $\begin{array}{c}K_{d} \\
\left(m^{-1}\right)\end{array}$ & $\begin{array}{l}\text { WT } \\
\left({ }^{\circ} \mathrm{C}\right)\end{array}$ & $\begin{array}{c}\text { SSC } \\
\left(\mathrm{g} \mathrm{L}^{-1}\right)\end{array}$ & $\left(\begin{array}{c}v \\
\left(\mathrm{~m} \mathrm{~s}^{-1}\right)\end{array}\right.$ & $\begin{array}{c}\text { RSi } \\
\left(\mathrm{mg} \mathrm{L}^{-1}\right)\end{array}$ & Main predators & Suitable river types for dominance \\
\hline RIa & MBFG I without flagella & $2.9-4.5$ & $>25$ & & $>1$ & & $\begin{array}{l}\text { Small and medium } \\
\text { zooplankton }\end{array}$ & \\
\hline $\mathrm{RIb}$ & MBFG I with flagella & $2.9-4.5$ & $20-25$ & & $>1$ & & $\begin{array}{l}\text { Medium and large } \\
\text { zooplankton }\end{array}$ & $\begin{array}{l}\text { Upperstream of higher rivers } \\
\text { in mountains }\end{array}$ \\
\hline RIIa & MBFG II & $>4.5$ & $<22$ & $<0.06$ & & & All zooplankton & \\
\hline RIIb & MBFG V with exoskeleton & $<4.5$ & $<20$ & $>0.1$ & & & & \\
\hline RIII & MBFG III but ignoring aerotopes & $>4.5$ & $>22$ & & & & Copepods & Downstream of lower rivers \\
\hline RIV & MBFG IV & $<2.9$ & $>20$ & & $>1$ & & $\begin{array}{l}\text { Medium and large } \\
\text { zooplankton }\end{array}$ & \\
\hline RV & MBFG V without exoskeleton & $<4.5$ & $<20$ & $<0.1$ & & & & Downstream of lower rivers in plains \\
\hline RVIa & MBFG VI of small size & $>4.5$ & $<22$ & $>0.06$ & & $<1.5$ & $\begin{array}{l}\text { Small and } \\
\text { medium rotifers }\end{array}$ & Downstream of plain rivers \\
\hline RVIb & MBFG VI of large size & $>4.5$ & $<22$ & $>0.06$ & $>2$ & $>1.5$ & & \\
\hline RVIc & MBFG VI of colony & $>4.5$ & $<22$ & $>0.06$ & $<2$ & $>1.5$ & Copepods & Downstream of plain rivers \\
\hline RVII & MBFG VII & $<4.5$ & $>20$ & & & & & Downstream of lower rivers in plains \\
\hline
\end{tabular}

$K_{d}$, light attenuation coefficient; WT, water temperature; SSC, suspended sediment concentration; v, flow velocity; RSi, soluble reactive silicate. 
properties among phytoplankton. Morphological traits are closely related to the water environment. $\mathrm{MBFG}_{\mathrm{R}}$ overcomes the low sensitivity of MBFG for better application in rivers. Undoubtedly, the morphological approach is an efficient tool to explore the effects of hydrological, physicochemical, and food web changes on potamoplankton independently from the geographical location and specific composition, although such approaches are not consummate (Mihaljević et al., 2013). The use of a morphological approach can lead to a better understanding of the ecological processes concerning riverine phytoplankton.

\section{ACKNOWLEDGMENTS}

This research has been sponsored by the project of $\mathrm{Na}-$ tional Natural Science Fund (51279060).

\section{REFERENCES}

Abonyi A, Leitão M, Stanković I, Borics G, Várbíró G, Padisák J, 2014. A large river (River Loire, France) survey to compare phytoplankton functional approaches: do they display river zones in similar ways? Ecol. Indic. 46:11-22.

Akaike H, 1973. Information theory as an extension of the maximum likelihood principle, p. 267-281. Proceedings $2^{\text {nd }}$ Int. Symposium on Information Theory, Akademiai Kiado, Budapest.

Boukal DS, 2014. Trait-and size-based descriptions of trophic links in freshwater food webs: current status and perspectives. J. Limnol. 73:171-185.

Breiman L, 2001. Random forests. Mach Learn. 45:5-32.

Brose U, Jonsson T, Berlow EL, Warren P, Banasek-Richter C, Bersier L-F, Blanchard JL, Brey T, Carpenter SR, Blandenier M-FC, Cushing L, Dawah HA, Dell T, Edwards F, Harper-Smith S, Jacob U, Ledger ME, Martinez ND, Memmott J, Mintenbeck K, Pinnegar JK, Rall BC, Rayner TS, Reuman DC, Ruess L, Ulrich W, Williams RJ, Woodward G, Cohen JE, 2006. Consumer-resource body-size relationships in natural food webs. Ecology 87:2411-2417.

Centis B, Tolotti M, Salmaso N, 2010. Structure of the diatom community of the River Adige (North-Eastern Italy) along a hydrological gradient. Hydrobiologia 639:37-42.

Christian D, Sheng YP, 2003. Relative influence of various water quality parameters on light attenuation in Indian River Lagoon. Estuar. Coast. Shelf. S. 57:961-971.

Cloern JE, Alpine AE, Cole BE, Wong RL, Arthur JF, Ball MD, 1983. River discharge controls phytoplankton dynamics in the northern San Francisco Bay estuary. Estuar. Coast. Shelf. S. $16: 415-429$.

De'ath G, Fabricius KE, 2000. Classification and regression trees: a powerful yet simple technique for ecological data analysis. Ecology 81:3178-3192.

De Emiliani MOG, 1997. Effects of water level fluctuations on phytoplankton in a river-floodplain lake system (Paraná River, Argentina). Hydrobiologia 357:1-15.

De Oliveira MD, Calheiros DF, 2000. Flood pulse influence on phytoplankton communities of the south Pantanal floodplain, Brazil. Hydrobiologia 427:101-112.

Devercelli M, O'farrell I, 2013. Factors affecting the structure and maintenance of phytoplankton functional groups in a nutrient rich lowland river. Limnologica 43:67-78.
Do, On SI, 1974. Adaptive change in plankton morphology in response to size-selective predation: a new hypothesis of cyclomorphosis. Limnology 19:721-729.

Dortch Q, Whitledge TE, 1992. Does nitrogen or silicon limit phytoplankton production in the Mississippi River plume and nearby regions? Cont Shelf Res. 12:1293-1309.

Duarte CM, Marrasé C, Vaqué D, Estrada M, 1990. Counting error and the quantitative analysis of phytoplankton communities. J. Plankton Res. 12:295-304.

Fraisse S, Bormans M, Lagadeuc Y, 2013. Morphofunctional traits reflect differences in phytoplankton community between rivers of contrasting flow regime. Aquat Ecol. 47:315-327.

Gómez N, Hualde P, Licursi M, Bauer D, 2004. Spring phytoplankton of Rio de la Plata: a temperate estuary of South America. Estuar. Coast. Shelf. S. 61:301-309.

Gallego I, Davidson TA, Jeppesen E, Pérez-Martínez C, Sánchez-Castillo P, Juan M, Fuentes-Rodríguez F, León D, Penalver P, Toja J, 2012. Taxonomic or ecological approaches? Searching for phytoplankton surrogates in the determination of richness and assemblage composition in ponds. Ecol. Indic. 18:575-585.

Gamier J, Billen G, Coste M, 1995. Seasonal succession of diatoms and Chlorophyceae in the drainage network of the Seine River: Observations and modeling. Limnol. Oceanogr. 40:750-765.

Gasol JM, 1994. A framework for the assessment of top-down vs. bottom-up control of heterotrophic nanoflagellate abundance. Mar. Ecol Prog Ser. 113:291-300.

Ger KA, Hansson LA, Lürling M, 2014. Understanding cyanobacteria-zooplankton interactions in a more eutrophic world. Freshwater Biol 59:1783-1798.

Gosselain V, Descy J-P, Everbecq E. 1994. The phytoplankton community of the River Meuse, Belgium: seasonal dynamics (year 1992) and the possible incidence of zooplankton grazing. Hydrobiologia 289:179-191.

Hamm CE, Merkel R, Springer O, Jurkojc P, Maier C, Prechtel $\mathrm{K}$, Smetacek V, 2003. Architecture and material properties of diatom shells provide effective mechanical protection. Nature 421:841-843.

Hasle J., 1978. The inverted microscope method, p 88-96. In: Sournia, A. (Ed.), Phytoplankton Manual. Unesco, Paris, France.

Hillebrand H, Dürselen CD, Kirschtel D, Pollingher U, Zohary T, 1999. Biovolume calculation for pelagic and benthic microalgae. J. Phycol. 35:403-424.

Hu R, Han B, Naselli-Flores L, 2013. Comparing biological classifications of freshwater phytoplankton: a case study from South China. Hydrobiologia 701:219-233.

Istvànovic $\mathrm{V}$, Honti $\mathrm{M}, 2011$. Phytoplankton growth in three rivers: The role of meroplankton and the benthic retention hypothesis. Limnol. Oceanogr. 56:1439-1452.

Izaguirre I, Allende L, Escaray R, Bustingorry J, Pérez G, Tell $\mathrm{G}, 2012$. Comparison of morpho-functional phytoplankton classifications in human-impacted shallow lakes with different stable states. Hydrobiologia 698:203-216.

Jansson M, Jonsson A, Andersson A, Karlsson JaN, 2010. Biomass and structure of planktonic communities along an air temperature gradient in subarctic Sweden. Freshwater Biol. 55:691-700.

Javornicky P, Komárková J, 1973. The changes in several parameters of plankton primary productivity in Slapy Reservoir 1960-1967, their mutual correlations and correlations with the main ecological factors. Hydrobiol. Stud. 2, Acad. 
Praha: 155-211.Köhler J, 1993. Growth, production and losses of phytoplankton in the lowland River Spree. I. Population dynamics. J. Plankton Res. 15:335-349.

Köhler J, Hoeg S, 2000. Phytoplankton selection in a river-lake system during two decades of changing nutrient supply. Hydrobiologia 424:13-24.

Kirk JTO, 1994. Light and photosynthesis in aquatic ecosystems. Cambridge university press.

Koski M, Schmidt K, Engström-Öst J, Viitasalo M, Jonasdottir S, Repka S, Sivonen K, 2002. Calanoid copepods feed and produce eggs in the presence of toxic cyanobacteria Nodularia spumigena. Limnol. Oceanogr. 47:878-885.

Kruk C, Huszar VL, Peeters ET, Bonilla S, Costa L, L rling M, Reynolds CS, Scheffer M, 2010. A morphological classification capturing functional variation in phytoplankton. Freshwater Biol. 55:614-627.

Kruk C, Segura A, 2012. The habitat template of phytoplankton morphology-based functional groups. Hydrobiologia 698:191-202.

Lau RK, Kwok A, Chan W, Zhang T, Wong JT, 2007. Mechanical characterization of cellulosic thecal plates in dinoflagellates by nanoindentation. J. Nanosci. Nanotechnol. 7:452-457.

Lund JWG, Kipling C, Cren ED, 1958. The inverted microscope method of estimating algal numbers and the statistical basis of estimations by counting. Hydrobiologia 11:143-170.

May CL, Koseff JR, Lucas LV, Cloern JE, Schoellhamer DH, 2003. Effects of spatial and temporal variability of turbidity on phytoplankton blooms. Mar. Ecol. Prog. Ser. 254:111-128.

Mihaljević M, Špoljarić D, Stević F, Pfeiffer TŽ, 2013. Assessment of flood-induced changes of phytoplankton along a river-floodplain system using the morpho-functional approach. Environ. Monit. Assess. 185:8601-8619.

Mihaljević M, Stević F, Špoljarić D, Pfeiffer TŽ, 2015. Spatial pattern of phytoplankton based on the morphology-based functional approach along a river-floodplain gradient. River Res. Appl. 31:228-238.

Muylaert K, Sabbe K, Vyverman W, 2000. Spatial and temporal dynamics of phytoplankton communities in a freshwater tidal estuary (Schelde, Belgium). Estuar. Coast. Shelf. S. 50:673-687.

Pacheco JP, Iglesias C, Meerhoff M, Fosalba C, Goyenola G, Teixeira-De Mello F, García S, Gelós M, García-Rodríguez F, 2010. Phytoplankton community structure in five subtropical shallow lakes with different trophic status (Uruguay): a morphology-based approach. Hydrobiologia 646:187-197.

Padisák J, Crossetti L, Naselli-Flores L, 2009. Use and misuse in the application of the phytoplankton functional classification: a critical review with updates. Hydrobiologia 621:1-19.

Padisák J, Soróczki-Pintér, Rezner Z. 2003. Sinking properties of some phytoplankton shapes and the relation of form resistance to morphological diversity of plankton - an experimental study. Hydrobiologia 500:243-257.

Phlips E, Cichra M, Aldridge F, Jembeck J, Hendrickson J, Brody R, 2000. Light availability and variations in phytoplankton standing crops in a nutrient-rich blackwater river. Limnol. Oceanogr. 45:916-929.

Reynolds CS, 1980. Phytoplankton assemblages and their periodicity in stratifying lake systems. Ecography 3:141-159.

Reynolds C, 1984. Phytoplankton periodicity: the interactions of form, function and environmental variability. Freshwater Biol. 14:111-142.

Reynolds CS, 1997. Vegetation processes in the pelagic: a model for ecosystem theory. Ecology Institute, Oldendorf/Luhe, Germany: $371 \mathrm{pp}$.

Reynolds C, Descy J-P, 1996. The production, biomass and structure of phytoplankton in large rivers. Hydrobiol. Suppl. Large Rivers 10:161-187.

Reynolds C, Descy J-P, Padisák J, 1994. Are phytoplankton dynamics in rivers so different from those in shallow lakes? Hydrobiologia 289:1-7.

Reynolds CS, Huszar V, Kruk C, Naselli-Flores L, Melo S, 2002. Towards a functional classification of the freshwater phytoplankton. J. Plankton Res. 24:417-428.

Søballe D, Kimmel B, 1987. A large-scale comparison of factors influencing phytoplankton abundance in rivers, lakes, and impoundments. Ecology 68:1943-1954.

Salmaso N, Naselli-Flores L, Padisák J, 2012. Impairing the largest and most productive forest on our planet: how do human activities impact phytoplankton? Hydrobiologia 698:375-384.

Salmaso N, Naselli-Flores L, Padisák J, 2014. Functional classifications and their application in phytoplankton ecology. Freshwater Biol. 60:603-619.

Salmaso N, Padisák J, 2007. Morpho-Functional Groups and phytoplankton development in two deep lakes (Lake Garda, Italy and Lake Stechlin, Germany). Hydrobiologia 578:97-112.

Salmaso N, Zignin A, 2010. At the extreme of physical gradients: phytoplankton in highly flushed, large rivers. Hydrobiologia 639:21-36.

Segura AM, Kruk C, Calliari D, Fort H, 2013. Use of a morphology-based functional approach to model phytoplankton community succession in a shallow subtropical lake. Freshwater Biol. 58:504-512.

Stanković I, Vlahović T, Udovič MG, Várbíró G, Borics G, 2012. Phytoplankton functional and morpho-functional approach in large floodplain rivers. Hydrobiologia 698:217-231.

Stoyneva MP. 1994. Shallows of the lower Danube as additional sources of potamoplankton. Hydrobiologia 289:171-178.

Tavernini S, Pierobon E, Viaroli P, 2011. Physical factors and dissolved reactive silica affect phytoplankton community structure and dynamics in a lowland eutrophic river (Po River, Italy). Hydrobiologia 669:213-225.

Train S, Rodrigues LC, 1997. Temporal fluctuations of the phytoplankton community of the Baía River, in the upper Paraná River floodplain, Mato Grosso do Sul, Brazil. Hydrobiologia 361:125-134.

Twombly S, Clancy N, Burns CW, 1998. Life history consequences of food quality in the freshwater copepod Boeckella triarticulata. Ecology 79:1711-1724.

Van Donk E, Ianora A, Vos M, 2011. Induced defences in marine and freshwater phytoplankton: a review. Hydrobiologia 668:3-19.

Várbíró G, cs , Borics G, rces K, Fehér G, Grigorszky I, Japport T, Kocsis G, Krasznai E, Nagy K, 2007. Use of Self-Organizing Maps (SOM) for characterization of riverine phytoplankton associations in Hungary. Hydrobiol. Suppl. Large Rivers 17:383-394.

Verschoor AM, Bekmezci OK, Ellen V, Vijverberg J, 2009. The ghost of herbivory past: slow defence relaxation in the chlorophyte Scenedesmus obliquus. J. Limnol. 68:327-335.

Wehr JD, Descy JP, 1998. Use of phytoplankton in large river management. J. Phycol. 34:741-749.

Wetzel R, 2001. Limnology: lake and river ecosystems. 3. Academic Press, London: 842 pp. 